\title{
Budgeting fundamentals analysis for the purposes of organizational budgetary policy development
}

\author{
Kira Gulpenko ${ }^{1}$, Natalia Tumashik ${ }^{1,{ }^{*}}$, Yulia Filiasova ${ }^{1}$, Narine Ritman ${ }^{1}$ \\ ${ }^{1}$ Saint-Petersburg State University of Economics, Sadovaya str., 21,St.-Petersburg, 191023, Russia
}

\begin{abstract}
Theoretical issues of budgeting are considered in the article. The essence of the concept, its subject and objects, budgeting principles, their scope and functions are examined. Theoretical positions on budgeting present in the economic literature are analyzed, and ultimately, the authors' views on fundamentals of budgeting are described.
\end{abstract}

\section{Introduction}

The current economic climate creates such a business environment which necessitates adopting new approaches to operations management of a business unit at all stages of the management cycle. Both in theory and in practice, there are various management techniques and tools that originated in the $19^{\text {th }}$ century and have been developing and improving until the present time. This situation is equally true for budgeting in different branches of economic activities.

In research papers, scientists do not give similar explanations of such notions as "budget", "budgeting", "budget management", "budget cycle", among others. As a result of academic literature analysis, it has been found that some authors consider a budget with respect to allocation of resources at a national level, others - to income and expenditure of a business unit. Therewith, one category of researchers define a budget as a detailed financial plan, another category of them - as a quantitative representation of a business plan as a number of physical and financial indicators for a certain budgeting period. In addition, a number of scientists describe a budget not only with regard to planned targets, but also - to actual performance indicators.

In general, each author expresses their own point of view, thus providing a complete description of the notion "budget" through adding new budgeting objects and through bringing it in accordance with goals to be achieved.

In this article, it is assumed that the notion "budget" is based on the following premises:

- the terms "national budget" and "the budget of a business unit" are not synonyms;

- the national budget is made from the perspective of its revenue and expenditure sides in monetary terms;

\footnotetext{
*Corresponding author: Tumnatdim@yandex.ru
} 
- generally, the budget is a regulatory legal act, on the one hand, and a system of economic relations developed in connection with provision, allocation and employment of resources, on the other hand;

- the budget of a business unit is considered as a planned document which becomes a basis for provision and allocation of material, human, financial and other resources, in conformity with goals to be achieved within fixed time frames;

- the budget of a business unit is an amount of resources allocated for a particular use under control of an organization department.

On balance, the budget of a business unit is a detailed plan of its activities as a whole and, at the same time, representing specific fields of concern - which is made in physical and monetary terms and is aimed at reaching particular goals within a specified period of time.

In learned treatises, the concept of budgeting is described through such terms as "technology", "process", "tool", "procedure", "technique", "system", "system element", "institution", "package of measures", and so forth.

As a result of scrupulous critical analysis, the following inferences can be made in relation to the considered approaches.

Authors and specialists interpret budgeting as a management technique implying different meanings of this notion.

The merit of V.E. Khrutsky's approach lies in employing a multifaceted approach to budgeting which includes financial planning, accounting and control [6]. The drawback of this method is a suggested list of budgeting objects confined to income and expenditure, which is insufficient for the purposes of managerial decision-making validity.

D.A. Shevchuk places a focus on business processes in defining budgeting as a management technology [7]. The author's position resides in the fact that the budgeting technology involves gathering information about business processes which is necessary for business process management.

Viewing budgeting as a technology, A.V. Rubis provides a considerable explication emphasizing the correlation between organizational budgeting and strategic planning [2].

The authors defining budgeting as a process in a broad sense reduce its meaning to the stages of planning, ratification, correction, approval, execution and control. In its strict sense, budgeting is interpreted only as a process of budget preparation and approval. The authors of the article suppose that budgeting should be regarded as a process of budget preparation for company activities and its subdivisions on the assumption of current objectives and strategic goals, as well as budget disbursement control for the purposes of taking corrective measures against deviations from budgetary performance indicators.

The authors of this article take sides with M.B. Trachenko's position who asserts that the approaches to budgeting as a technology and as a process are not alternative or mutually exclusive because the ultimate goal of a technology implies breaking down the process of achieving a certain result onto constituent elements [5].

The articulation of such a complex concept as budgeting by means of the notions "tool" and "technique" depends on technology and process. We suppose that it is insufficient to confine the role of budgeting only to the limits of a tool in the management and planning processes.

Budgeting as a system fulfills a number of functions; it consists of elements which possess systematically important properties, connections and relations; it also has a particular structure. In economics literature, the focus is placed on the properties and characteristics of a budgeting system. The authors of this article believe that budgeting is a complex and multifaceted system of organizational governance. 
A variety of scientific standpoints to the concept of budgeting results from the fact that this economic category:

- is used by specialists in various fields such as planning, management accounting, financial management, controlling, among others;

- is applied in different counties and causes misinterpretations of this idea when translated;

- develops rapidly and evolves in time.

Organizational budgeting is characterized by the corresponding goals which are presented in the economic literature from various perspectives. Some researchers equate budgeting targets to organizational goals; others equate them to budgeting functions. The authors of this article assume that budgeting goals should be considered in conjunction with the content of this economic concept. For instance, if budgeting is viewed as a constituent part of management accounting, its primary goal is providing managers with relevant information for managerial decision-making at all stages of a budgeting cycle.

A number of specialists subdivide budgeting goals into general and specific. The authors of this article presume that budgeting can reach several goals depending on time frames, areas of activity and their specification.

The subject area of budgeting is characterized by its objects related to the operations of a company in general and its sectors. According to the authors' view, the subject area can embrace both the total range of assets and business processes during the entire operations management cycle; and separate processes, operation groups, assets, liabilities, incomings, expenses, subdivisions or products depending on budgetary goals and objectives to be met.

In scientific literature, the subject of budgeting in a business unit is thought of as:

- mission statement of a company;

- business risks;

- $\quad$ prospective and actual performance indicators in financial and operational activities of a company, including deviations of target values from actual achievements.

Budgeting is closely related to the idea of budget management, which is considered as operational management system for responsibility centers on the basis of budget targets for reaching goals and efficacious utilizing of company resources, which is a constituent part of budgeting.

In modern conditions, the functionality of budgeting in a large company extends and involves:

- financial reasonability of management decisions at all levels of hierarchy;

- utilization efficiency of available resources, assets and supervisory liabilities at all management levels;

- provision for attraction estimability for particular areas of economic management;

- determination of investment policy directions;

- rationale for organizational restructuring alternatives;

- reinforcement of financial discipline and its combinability with organizational personnel motivation;

Budgeting is inextricably connected with planning. On the grounds of predicted results planning is exercised and an operating plan is developed. Planning involves defining and evaluating financial and non-financial goals of business development, determining effective roads of their achievement within specified time horizons. Planning resides in two independent business dimensions:

- the organizational dimension which involves selection of personnel for preparing plans, periodicity of their preparation, information transfer time and composition of its users, the system of plan revision; 
- the content-related dimension which establishes planning algorithms, sources of obtaining primary data and which determines economic rationale, primary data, outcome and so on.

Depending on the content of plans drawn up for different time horizons, three categories of planning are distinguished: strategic, tactical and operational.

Strategic planning is aimed at a long term perspective and is related to goal setting, business area and market definition, scale determination, customer targeting, partner selection, among others. Tactical planning, executed in the midterm, includes the adoption of strategy implementation approaches and the necessary resources. Short-term planning is targeted at current operations; its basic objective is specification of tactic plan indicators for the purposes of daily systematic and smooth company operations accomplishment, including all subdivisions and departments. Specified periods of time relating to strategic, tactic and operational planning are reliant on performance characteristics and scale of a company and can vary significantly.

Within the sphere of budgeting, income, expenditure, cash flow and other financial and non-financial indicators are planned which allow reaching company goals. V.Yu. Savin points out that "the difference between the notions "budgeting" and "planning" lies in the fact that budgeting is a framework for any planned activity, it provides structuring and detailed elaboration of information about an object intended for business planning within particular cost estimates. Simultaneously, budgeting is orientated towards an actualization of its high analytical functional potential" [4].

At the stage of budget utilization, factual information is complied in the system of management accounting which provides the realization of feedback principle. Budgets are implemented by responsibility centers; that leads to the necessity of introducing a system of internal control for monitoring their performance results.

Every scientific discipline typically applies its own range of principles. The study of the notion 'principle' is further elaborated in line with the development of scientific views and positions which is connected with the widening of the world view on phenomena happening in society and coming into focus of academic research [1].

The content of such a concept as 'principle' is considered in wide sense which allows analyzing related principles in each particular discipline [1] - their substantiation, interpretation and, in the presence of a large quantity of principles, - their classification [1]. In this context, the appropriateness of E.E. Rumyantseva's viewpoint is evident:

- "ontological (the aspect includes the genesis of principles, their relationships with the nature, essence, and role of those regularities, relations and interconnections which they reflect);

- gnoseological (the analysis of the nature of principles, language, logic and structure, their correspondence to scientific fundamentals);

- methodological (which describes application mechanisms of theoretical and practical principles)" [3].

\section{Methodology}

Principles reside in the basis of budgeting rules and all its constituents including methodology, planning arrangement and budget execution control.

Table 1 presents budgeting principles and their content; their application enables budget planning and its realization by a business unit. 
Table 1. Budgeting principles, described in economic literature.

\begin{tabular}{|c|c|}
\hline Budgeting Principles & Principle Content \\
\hline $\begin{array}{l}\text { Interrelation between } \\
\text { strategic, current plans } \\
\text { and budgets }\end{array}$ & $\begin{array}{l}\text { Consistency among strategic and tactic company goals and } \\
\text { budgetary indicators approved for a certain budgetary period }\end{array}$ \\
\hline $\begin{array}{l}\text { Monetary terms and } \\
\text { quantification }\end{array}$ & $\begin{array}{l}\text { Budgetary indicators are expressed in physical and monetary } \\
\text { measures. However, the plan, apart from budgetary } \\
\text { numerical values, normally includes a list of particular events } \\
\text { for meeting those goals. }\end{array}$ \\
\hline Determination in time & $\begin{array}{l}\text { A budget is developed and adopted for a certain budgetary } \\
\text { period which has time frames. }\end{array}$ \\
\hline Budgetary frequency & $\begin{array}{l}\text { A budgetary period has a particular length. Company budgets } \\
\text { are prepared on a yearly basis with a breakdown into } \\
\text { minimal budgetary periods. }\end{array}$ \\
\hline Flexibility & $\begin{array}{l}\text { Capacity for transformation due to modifying internal and } \\
\text { external conditions }\end{array}$ \\
\hline Centralization & $\begin{array}{l}\text { Budget preparation process can be performed "from top } \\
\text { downwards" and "from the bottom upwards". The first } \\
\text { variant involves preparation of budgets by a specialized } \\
\text { service and its recommendation to organization departments } \\
\text { for action; the second variant - participation of organization } \\
\text { departments in budget preparation. However, ultimately, the } \\
\text { approval of budgetary indicators is carried out by senior } \\
\text { managers of a company. }\end{array}$ \\
\hline Systematic approach & $\begin{array}{l}\text { Budgetary indicators for selected departments and segments } \\
\text { are adopted in reliance on maximization of final results at an } \\
\text { enterprise in general, but not efficiency enhancement of a } \\
\text { separate segment. }\end{array}$ \\
\hline Information relevancy & $\begin{array}{l}\text { Specification of indicators in a particular budget form and } \\
\text { deviations in accounts and records, revealed at the stage of } \\
\text { budget performance monitoring, depend on the relevancy of } \\
\text { information for taking managerial decisions. }\end{array}$ \\
\hline Prospects & $\begin{array}{l}\text { Preliminary description of financial goals of an enterprise } \\
\text { and its departments in the form of assignments according to } \\
\text { determined norms. Budgets include indicators which have } \\
\text { projected values and characterize future activities of an } \\
\text { enterprise in general and its segments in particular. }\end{array}$ \\
\hline Complexity & $\begin{array}{l}\text { When preparing budgets it is necessary to take into account } \\
\text { the effect of external and internal factors. External factors } \\
\text { embrace competition, social life, scientific and technological } \\
\text { progress, macro- and microeconomic situation, political } \\
\text { climate; internal factors are production, organization, human } \\
\text { resources, research and development. }\end{array}$ \\
\hline Coordination & $\begin{array}{l}\text { The process of budget preparation and approval involves } \\
\text { interest alignment between the entire enterprise, its } \\
\text { departments and employees. }\end{array}$ \\
\hline Continuity & $\begin{array}{l}\text { The procedure of budget compilation involves revision of } \\
\text { previous forecasts for the budgetary period before the } \\
\text { expiration of the current period on the basis of the operating } \\
\text { control and analysis of the current budget utilization taking } \\
\text { into account modification of external factors. }\end{array}$ \\
\hline Multivariance & $\begin{array}{l}\text { The budgeting process investigates various scenarios for the } \\
\text { development of external and internal environments through a } \\
\text { system of flexible budgets. }\end{array}$ \\
\hline Confidentiality & $\begin{array}{l}\text { Compliance with the rules of commercial confidentiality in } \\
\text { relation to the information about organizational budgeting }\end{array}$ \\
\hline
\end{tabular}




\begin{tabular}{|l|l|}
\hline Standardization & $\begin{array}{l}\text { For the purpose of regulation, transparency and consistency, } \\
\text { it is necessary to standardize budgetary forms, procedures } \\
\text { and budgeting rules for managing an enterprise and its } \\
\text { departments. }\end{array}$ \\
\hline Indicator reality & $\begin{array}{l}\text { When preparing budgets, budget indicators should not be } \\
\text { overvalued or undervalued. }\end{array}$ \\
\hline Analyticity & $\begin{array}{l}\text { Indicators, which can be found in reports, should be } \\
\text { presented in a convenient view without requiring any } \\
\text { additional analytical processing or reverse synthetic } \\
\text { procedures. }\end{array}$ \\
\hline Compatibility & $\begin{array}{l}\text { Budget indicators and report results should be compatible } \\
\text { with the aims of budget execution monitoring and analysis. }\end{array}$ \\
\hline Personal responsibility & $\begin{array}{l}\text { One of the main organizational aspects of budgeting is the } \\
\text { development of a financial structure integrated into financial } \\
\text { responsibility centers for the purpose of liability allocation to } \\
\text { certain senior executives for executing budget indicators } \\
\text { under control. }\end{array}$ \\
\hline $\begin{array}{l}\text { Availability of quality } \\
\text { criteria }\end{array}$ & $\begin{array}{l}\text { It is necessary to determine indicators which characterize the } \\
\text { quality of budget utilization with an aim of performance } \\
\text { evaluation at the financial liability centers and development } \\
\text { of an incentive scheme. }\end{array}$ \\
\hline Transparency & $\begin{array}{l}\text { Lucidity and availability of budgetary information, real } \\
\text { opportunities to exercise control over its execution }\end{array}$ \\
\hline Efficiency & $\begin{array}{l}\text { Expenditure on execution of a budgeting process should not } \\
\text { exceed economic benefits from a budget as a tool of planning } \\
\text { and control }\end{array}$ \\
\hline
\end{tabular}

The content of the table witnesses a diversity of budgeting principles as the budgeting methodology is based on interrelations with scientific aspects of economic methods and techniques alongside concepts in various scientific disciplines in the system of knowledge.

In practice, budgeting fulfills a number of functions which are described in the economic literature by different authors in the context of their interpretations and findings. A common approach to the composition and content of those functions is missing from academic literature; such a situation results from a variety of interpretations of the term "budgeting", its multiple goals and objectives, its multifaceted subject and objects.

The authors of the article consider that "budgeting functions" should be analyzed in a broad sense of this term which is referred to the system of budgeting and applied by business units for achieving various goals in practice. To this end, the following budgeting functions should be reported here:

1. A budget is a tool used for operating planning. A plan contains company goals set for a certain period of time, while budgets help determine ways of reaching those goals, in other words, usage of resources with regard to available and predicted opportunities and efficiency.

2. Budgets fulfill the function of coordination which involves providing interconnections among various kinds of activities and different organizational departments, also alignment of interests among separate employees and groups of staff members inside the company.

3. The function of motivation aimed at senior executives at all levels and ordinary personnel, for reaching goals of financial responsibility centers and the enterprise, involves development of an incentive system which includes financial incentives as one of its constituent elements. The system of financial incentives is realized on the 
basis of performance indicator analysis, databases, bonus ratios, their calculation methodology and other conditions - for each responsibility center.

4. A budget is a means of control and organizational operating performance analysis. Execution of this function includes:

- drafting internal accounts and reports;

- comparing factual and budget indicators;

- analysing factors which could affect the achieved result;

- matching budget indicators to organizational goals.

5. The audit function makes it possible to recognize problem areas which require primary attention, to identify new opportunities which were not described at the stage of budget preparation, to correct budget indicators if the original budget seems unrealistic to a certain degree.

6. Financial responsibility centers develop assessment criteria and management estimates which are included in budgets afterwards. The evaluation of budget execution is performed by centers for financial responsibility on the basis of indicator analysis which involves identifying causes of disagreements between actual and budget values. The evaluation of budget execution by the centers for financial responsibility serves as a basis for company-wide incentive scheme application.

7. The communicative function of budgets involves disseminating information among employees through information budgets about production and financial aspects of the company activities. Information transfer is carried out from low-level managers to senior executives and vice versa.

8. Budgets act as training aid for managers.

Managers who take part in budget preparation and agreement study their department activities in detail, monitor and compare relations between indicators of their own responsibility center and other centers.

In sum, the study of opinions expressed by researchers and specialists who investigate the essence of budgets and determine budgeting rules and function at the level of a business unit, showed that under modern conditions budgeting is executed at all stages of a management cycle. The latter is the sum total and a sequence of repetitive processes: forecasting, planning, execution, audit, analysis, and regulation - all these involve managerial actions aimed at meeting managerial challenges and achieving organizational goals.

\section{Conclusion}

'Budget' is a well-established concept. However, the modern economic environment necessitates developing new approaches for the purposes of organizational governance depending on the internal organizational climate in a business unit and its goals and objectives to be met. Currently, the scope of budgeting incorporates a variety of scientific positions as this economic category is intensively developing and transforming in time, involving specialist expertise in such areas as management, economics, governance, controlling and others. The subject area of budgeting, its purpose and principles whose application enables its implementation have been considered. The articulation of budgeting principles is associated with and contributes to the analysis of the entire management cycle in an organization. 


\section{References}

1. K.V. Gulpenko, N.V.Tumashik, Theoretical aspects of auditing principles(KUPRIENKO SV, Odessa, 2014)

2. A.V. Rubis, Budgeting-based internal planning system control of an industrial enterprise(Economic Sciences, Vladivostok, 2008)

3. E.E. Rumiantseva, New Encyclopedia (INFRA-M, Moscow, 2011)

4. V.Yu. Savin, Auditing and Financial Analysis 2, 34-41 (2011)

5. M.B. Trachenko, Author's Abstract of Doctoral Dissertation in Economic Sciences 1, 38 (2012)

6. B.E. Khrutsky, V.V.Gazmaiunov, A Handbook on Fundamentals of Financial Budgeting (Finance and Statistics, Moscow, 2007)

7. D.A. Shevchuk, Budgeting: Tutorial(RIO Publishing house,Moscow, 2006) 